\title{
Social Enterprises in Canada: An Introduction
}

\author{
J.J. McMurtry
}

York University

François Brouard

Carleton University

\section{INTRODUCTION}

This special edition of ANSERJ is the result of two years of labour by researchers across Canada as part of the "International Comparative Social Enterprise Models" (ICSEM) project. The objective of this special edition is twofold: First, to provide researchers access to this cutting edge research, which examines social enterprises as they emerge amongst regional and cultural groups within Canada and, second, to provide a theoretical and practical "snapshot" of social enterprise at this important historical juncture. We hope that by taking and sharing such a snapshot, research on social enterprise in Canada and globally can be advanced. Therefore these articles focus on outlining the practice of social enterprises in various regions as it is emerging and not on final conclusions or singular interpretations. We believe however that on balance, given the surge in interest in social enterprise amongst practitioners, policy makers, academics and the public at large, the risks of publishing emergent research are outweighed by the benefits of moving the conversation on social enterprise forward.

The articles that follow in this special edition are organized around geographical and cultural groups, outlining regional differences in the historical development and conceptual understanding of social enterprises across Canada. This introduction has been constructed to provide an overview of these articles, providing a high level analysis of the national characteristics of social enterprises in the regionally and culturally diverse country of Canada. For those interested in a more fully articulated version of this overview of the Canadian social enterprise landscape, they can look towards the Canadian report in forthcoming ICSEM working paper series, from which significant components of this introduction have been drawn. (Please see the ICSEM Canada website for further information on this project or to read the Canadian or Quebec reports: http://httpserver.carleton.ca/ fbrouard//CSEMCanadagroup .) 


\section{McMurtry \& Brouard (2015)}

The main findings of the Canadian ICSEM report are that there are five main types of social enterprise practice in Canada, which cut across the cultural and policy regimes: cooperatives, nonprofit organizations, community development/interest organizations, Indigenous businesses, and business with a social mission. Further, the report argues that social enterprises are not simply the result of the activities of entrepreneurs, either collective or individual, but also provincial government legislation and major enabling institutions (e.g., university institutions, social networks and movements, entrepreneurial spaces, and funding agencies) that have a major influence on how we can understand the context and emergence of social enterprise models.

This introduction will therefore outline the legislative, conceptual, and social enterprise models that frame the emergence of social enterprise in Canada. It is our hope that by so doing, we will provide a context within which the more focused regional articles that make up this special edition can be more broadly understood.

\section{UNDERSTANDING THE CANADIAN SOCIAL ENTERPRISE LEGISLATIVE CONTEXT}

Most readers will know that Canada is divided geographically into ten provinces and three territories and five main regions (Atlantic Canada, Québec, Ontario, Western Canada and the territories of the North). These geographical and regional contexts are important because they form in significant ways the legislative frameworks within which social enterprises emerge. Legislatively, Canada is governed at four levels: the federal, provincial/territorial, local/municipal levels and by Indigenous governments. Legislative responsibilities are divided between the different levels of government based on a long history of colonization and decolonization, which has created significant overlap and tensions between the various levels' governments around policy jurisdiction. This ambiguity, and sometimes outright conflict, at the legislative level creates numerous problems for emerging sectors and institutions, such as social enterprise, because it is not entirely clear which level of governmental jurisdiction they fall under, whose responsibility it is to promote these kinds of activity, how to harmonize these policies, and how to facilitate and formalize activity that emerges from the activity of practitioners as opposed to politicians. Finally, some government initiatives are seen in the context of colonialization (especially in the Francophone and Indigenous communities), which hampers the development of clear national policies, practices, or frameworks. At the same time, the diversity of institutional and cultural contexts within a single nation creates room for experimentation and learning.

The diversity of Canadian cultural and legislative contexts has had a significant influence on the emergence and practice of social enterprise in Canada. Social enterprises have embedded themselves, or are embedded in, these legal and cultural communities in important ways. Therefore to talk about social enterprises in Canada means that one must discuss the uniquely regional and cultural context within which they emerge. Even within regional and cultural contexts, some significant tensions exist. For example, in Québec social enterprise is not the dominant concept in the francophone community, who prefer generally to refer to the social economy. This is the result of significant and impressive work by a number of social movements and groups-notably the Chantier de l'économie sociale-but is not universally shared by other communities such as the affluent English community in Montreal (see the article by Bouchard, Cruz Filho, \& Zerdani in this edition). In Atlantic Canada, there is a strong sense of place and history that influences how social enterprises develop and are seen by practitioners and policy makers, even if there is not complete consensus on this concept (see Lionais in this edition). In Ontario, its situation as the historical financial and economic centre of Canada has deeply coloured the development of social enterprise in this province, with a strong focus on the enterprise side of the equation, but also features strong collective and social organizations that cut against this trend (see Brouard, McMurtry, and Vieta in this edition). In Western Canada, specifically Alberta and British Columbia, there is a history of 


\section{McMurtry \& Brouard (2015)}

more right of centre governments (similar to Ontario in the 1990s) that have created an environment that has been conducive to innovations of social service delivery more independent of the state, but these feature a range of organizations and solutions to the problem (see Elson and Hall in this edition). Finally, Indigenous communities across the country have become increasingly involved in social enterprise development, but within the challenging contexts of demographic trends, colonial legacies, poverty and social exclusion (see Sengupta, Vieta, and McMurtry in this edition). Consequently, for every assertion that follows about practices and typologies, it is important to remember that there are innovations and practices on the ground that challenge these claims. Therefore, readers should exercise caution with the necessary generalizations on the nature and practice of social enterprise that emerge below.

\section{UNDERSTANDING CONCEPTS AND CONTEXT}

There are three ways that the emergence of social enterprise in Canada can be framed-historical, contextual, and conceptual. As mentioned above, social enterprise is contested as a concept and a practice in Canada, and this introduction now turns towards developing an understanding of social enterprise in Canada that is sensitive to the differences, while articulating the similarities, of this emerging sector.

\section{Historical}

A significant reason for the difficulty of establishing an agreed upon conception of social enterprise in the Canadian context is the fact that the term has largely come from "outside" of existing practices and cultural histories. This is to say that there were similar longstanding, unique, and specific practices that had developed in specific contexts long before the concept of social enterprise began to emerge. Further, these established practices, for example co-operatives, mutuals, or market-oriented nonprofits, have seen numerous "framing" concepts come and go (such as community economic development, the third sector, social economy, social purpose businesses) without necessarily leading to improvements in public awareness or legislative frameworks that would have facilitated their work. Indeed, one of the key experiences of the practitioners of social enterprise is that the concept is not one of their own making, but rather a concept that has taken hold in the minds of the public, policy makers, and, significantly, business and has been applied to them. Further, the cultural contexts within which these terms are employed (see for example McMurtry 2010) have developed independently of each other, and reflect significantly different historical realities. Most basically the Indigenous, Anglophone, and Francophone communities have all had very different religious, colonial, and political realities since colonization, which cannot simply be erased by new academic definitions or government priorities.

This experience of social enterprise coming from "outside" has meant that for some communities the concept is treated with suspicion. For example, in Indigenous communities the idea of any Federal or Provincial policy encouraging a particular type of business in these communities can be seen in the context of colonializationespecially given the history of residential schools that forcibly took young Indigenous children away from their families in the name of providing "a better future" (see Sengupta, Vieta, and McMurtry in this edition). Or in the case of Québec, Federal government programs have historically been imposed on the Francophone population without consultation, which has created a climate of suspicion towards any such policy. Since social enterprise combines the idea of a social mission with business activity, questions such as whose social mission is being forefronted, by precisely which business means or operations, and in the service of what end, must be confronted within the layered and complex Canadian context. 


\section{McMurtry \& Brouard (2015)}

Despite these limitations to the concept of social enterprise, the authors of this special edition have identified five endogenous cultural groupings to focus the articles in this journal; namely Atlantic Canada, Québec, Ontario, Western Canada and the North, and First Peoples. Within these groupings, we can also identify three important gateways for policy development on social enterprise-municipal/band government, provincial government and national government-which can have differential and sometimes contradictory understandings of social enterprise. Further, there are strong articulations of policy needs and practices of social enterprise within communities and social movements that have, for example in the case of Québec, impacted policy frameworks and can with confidence be looked on as sites of future policy development. These endogenous cultural groupings do not operate completely in a vacuum, but rather are coloured by the surrounding context of forces that are at play around them.

\section{Contextual}

We therefore must look at the larger context of social, political, and economic forces within which the practice of social enterprise has emerged in Canada to contextualize the articles that follow. In short, we must recognize that the five cultural groupings identified above are not just endogenous in their formation, but are heavily influenced by exogenous factors in ways that are somewhat unique, but that are also informed by comparison, learning, and exchange. We have identified five exogenous influences that have differential impacts on social enterprise development in Canada: the United States of America, the United Kingdom, continental Europe, Indigenous' history and traditional practices, and a wide variety of immigrant communities. None of these influences is singular or homogenous, but it is important to recognize their impacts and unique influences. It is also important to note that many social enterprises rely on government funding in one way or another to support their social purpose.

These five influences are often contradictory in the direction they provide for social enterprise. First, there is the strong influence of the United States and its focus on entrepreneurship and self-sufficiency-an influence that is especially powerful in Canadian Anglophone communities. Thus the dominant formulation of social enterprise in the Western, Ontario, and Atlantic regions as well as the Territories, especially from the point of view of government and funding bodies, is one that focuses on individual entrepreneurs creating successful businesses that have, as an important element, a broadly construed social purpose (e.g., employment or environmental need). This focus highlights the important difference between social entrepreneurs and social enterprises in terms of the emergence of social enterprise policy, practice, and public awareness.

Secondly, and relatedly, there is the influence of the social enterprise movement in the UK, which is similar to that in the United States but with a more socially focused and developed policy component that has elements of community ownership and social care, growing as it did out of a more extensively developed, and more extensively retrenched, welfare state system. Thus the state can create policies (for example, the Green Energy Act in Ontario, which brings in a Feed-In-Tariff and community ownership models for alternative energy in the context of an increasingly deregulated energy grid) that encourage community ownership and control, as well as opportunities for social entrepreneurs. Or, as will be discussed below, the idea of a Community Interest Corporation has begun to take hold, especially in the Atlantic region, building on the experience in England. Again, this "British" model is gaining increasing political acceptance in Anglophone communities especially in policy, although implementation is underdeveloped and contested both politically and socially.

Thirdly, and this is particularly true of Francophone and immigrant communities, there is the influence of a continental European understanding of social enterprise in line with the EMES definition, especially in Québec. This conception tends to focus strongly on social movements and solidarity economics, with a focus also on 


\section{McMurtry \& Brouard (2015)}

democratic practice and community control. While these practices are by no means dominant outside of Québec, they have strong roots in a variety of locations and communities. In fact, one can see hybrids of the first three forms in almost every jurisdiction in Canada.

Fourthly, Indigenous communities have developed their own understanding of social enterprise from their long history of colonial exploitation, experiences of racism, and economic marginalization. While not "outside" of the history of Canada per say, the influence of the innovations of some Indigenous communities on others can be seen as an exogenous influence. Indigenous communities across Canada also share a relationship to the federal government in a variety of policy arenas that are located at the provincial level for non-Indigenous communities, including governance, infrastructure, housing, and education. Crucial in these communities is the often-overlooked and shared fact that officially there is collective and generational ownership of reserve land, which creates opportunities (collective ownership) and barriers (no collateral for capital) to social enterprise development. These communities tend to have a focus on community economic development and, unlike other communities, less suspicion of large corporations (for example Membertou First Nation in Sydney, Nova Scotia) participating in that community economic development (from resource extraction to tourism), which forms another exogenous influence.

Finally, as a largely settler nation with a continuing and strong tradition of immigration, it is important to acknowledge the role that Canada's increasingly diverse (and urban) immigrant communities are playing in innovating within the field of social enterprise. These communities both influence social enterprise development through the innovations that they implement in order to acclimatize to unfriendly and often hostile conditions as well as through their contributions of forms of social enterprise that they bring from their experiences in the countries from which they came.

\section{Conceptual}

As a result of the wide range of cultures, regions, and influences in the Canadian social enterprise context, it should be no surprise that there are debates and tensions around the conceptualization of social enterprise in Canada. The ways in which these debates play out often reflect the historical and cultural contexts that are specific to Canada. There are consequently tensions in the patterns of emergence of these concepts that range from social movement articulation (i.e., the emergence of social economy in Québec, or place-based business in Eastern Canada) to government imposition through policy (e.g., Ontario's creation of "community cooperatives" for alternative energy or its Impact Plan for Social Enterprise) that often happens without consultation of established organizations and movement players. Finally, the concept of social enterprise has in certain cases been "hijacked" by established for-profit businesses that enjoy the "branding" advantage that the idea of social enterprise brings. All of these disagreements create a climate of contestation and confusion in the public sphere, which does, and will continue to have, an impact on the practice of social enterprise as it develops. In other words, what forms a social enterprise "should" or "could" take are not yet fully articulated (and perhaps should not be), and the idea of a standard typology is not firmly established nationally, despite the fact that there are strong regional understandings and practices (Elson \& Hall 2012).

Despite all of these tensions however the undeniable reality across Canada is that social enterprise is a concept and practice that is taking hold "on the ground," and is a creative, emerging sector of the economy. Further, while not dominant, it is a concept that is explicitly used in every area of the country and has been formalized in legislation in a variety of jurisdictions. Academics and civil society activists have also taken up the term in a variety of ways, but the fact is that policy makers, academics, and activists are just starting to catch up to the 


\section{McMurtry \& Brouard (2015)}

innovations on the ground. These innovations are identified within the articles that follow.

Given this rich tapestry of understanding, practice, and influence, the authors of this special edition took several basic typology approaches to frame their articles. The first is the EMES typology, which helps identify three key components of social enterprise: economic and entrepreneurial; social; and participatory governance. While there are a wide variety of "levels" of each of these three areas in each cultural region, this typology was useful in terms of establishing qualitative features of social enterprises. Even in the "absence" of some of these features, this definition was useful in identifying and examining social enterprise in a variety of contexts. In the Atlantic Canadian and Québec articles the EMES definition has had the most impact, but there are important exceptions. In the Atlantic Canada article the notions of "place" and "community" are particularly strong components of social enterprise (perhaps a result of the long history of this region's economic and geographic isolation), and in the Québec article the idea of the social economy, which has strong elements of solidarity and social movement concerns as a result of hard-won experience of establishing the social economy in policy and practice, was seen as crucial to their self-conception and in many ways antithetical to the emergence of social enterprise in the North American context (see above).

Elson, Hall, Leeson-Klym, Penner, and Andres, authors of the Western article, develop a second framework for social enterprise, describing a view of social enterprise as emergent and not yet established enough for solid typologies. However, they used a framework to mix the "taxonomy" approach to social enterprises (a focus on the legal and ownership structure of social enterprises) with a more qualitative approach that looks at the purpose and values of social enterprises. Third, Madill et al. (2010) focus on the dimensions of social transformation, financial self-sufficiency and innovation to examine social enterprises. Fourth, Bouchard et al. (2013) analyze a number of typologies and retain four dimensions between social purpose and economic activity, namely democratic governance, autonomy and independence, limited or prohibited profit distribution and organized production of goods and services. Again, those frameworks were considered by the researchers to be guides, rather than "set-in-stone" definitions, and this has led to unique interpretations of the practice of social enterprise in each cultural and regional context.

One can add to this debate the hesitation of some Indigenous scholars (e.g., Wuttunee 2010), who reject both the concepts of social economy and social enterprise as colonial impositions, preferring to conceive of economic activity owned and operated by Indigenous as "community capitalism." Further, in Western Canada and Ontario and for Indigenous peoples, the concept of participatory governance was not seen as important to the concept of social enterprise (for different reasons); rather the focus was on economic activity in the service of some kind of social impact. We therefore look in this special edition not to impose a single typology on Canada or any of the cultural regions, but to incorporate the elements of these definitions that are most applicable to the various contexts.

Finally, it is important to highlight that in the Canadian context there are four important larger interrelated ideological contexts that colour the debate on social enterprise across the country and within each cultural region; such ideological contexts are related to the historical and contextual issues outlined above. The first is the emergence, since the 1980s, of an increasingly hegemonic neo-liberal policy and economic framework. This ideological climate has been both an inspiration to, and limit for, the emergence of social enterprise in Canada and has pushed policy and practitioners towards an increasingly economic focused, competitive, and individualistic conception. Secondly, since the deep recession began, in 2008, there has been a climate of 


\section{McMurtry \& Brouard (2015)}

austerity in the Canadian, and indeed global, context which influences how social enterprises are seenincreasingly as more cost-effective providers of service delivery for governments-and the funding available for them. Arguably, however, the Canadian experience with austerity has deeper roots, to the budget cutbacks of the mid-1990s. Third, this climate of austerity has increased the pressure on social enterprise in Canada through the downloading of social services to regions or municipalities (the most emblematic of these are service cuts to Employment Insurance and cuts to the transfer payments from the Federal to Provincial governments). One way in which this impulse has been expressed in the Canadian context is through the insistence/valorization of "partnerships" as a mode of service delivery-so opening the door to sub-national engagement with the sector. Fourthly, there has been a retreat of the Welfare State over the last 35 years that has led to a belief that the state is not an efficient provider of social services, coupled with the promotion of notions of self-sufficiency for communities and community organizations. This has meant that there is increasing interest in social enterprise as a "third way" for the provision of social good, but also that there is increasing pressure on social enterprises to prove that they are an efficient way to deliver these social goods.

These four ideological contexts influence conceptions of social enterprise in different regions and also help identify different social responses from the representation of this ideological climate, one which ranges from providing an opportunity for the "heroic" entrepreneur to a clarion call to civil society to foster collective entrepreneurship in response to the negative social impacts of these ideological agendas. The conceptual climate of social enterprise, while contested, has important shared elements, which we follow through in the section below.

\section{Identification of social enterprise (SE) models}

Now that the historical, contextual, and conceptual frameworks have been outlined, this introduction concludes with identifying a social enterprise typology that focuses on both the diverse practice and the values of social enterprise activity in Canada. To do so we highlight five types of practice in the country that are emblematic of social enterprise and are present-although unevenly developed-in all cultural contexts. We have taken this approach to get past the "noise" of social enterprise discussion and look at how it is actually practiced on the ground. From these practices we have identified certain values within social enterprise in the Canadian context.

We must remember that given the different histories and practices of the various social enterprises in Canada, these organizations have a desire to be classified in a number of different ways, depending on the audience and what is at stake in the classification (funding, public perception, regulatory rules, political climate, etc.). For example, cooperatives in Canada will variously identify as: social enterprises, social economy organizations, cooperatives, successful for-profit businesses, and sustainable, "green," and "good" enterprises. The issue for researchers is to penetrate these discourses by identifying the cultural, economic, and political contexts within which they are employed and look to how cooperatives actually practice their values and undertake their business. From the various case studies undertaken in the region reports outlined above, we were struck as authors at the consistency of forms of social enterprise, as well as the value propositions they articulated in their practices.

Despite the different theories of social enterprise mentioned above, we identified five main sets of social enterprise practice that cut across the cultural and policy regimes: cooperatives, market-oriented nonprofit organizations, community development/interest organizations, Indigenous businesses, and business with a social mission. We identify these five models because they have clear, if diverse, fields of activity, distinct social missions and target groups, legislative supports, and governance models. Perhaps most importantly, they are 


\section{McMurtry \& Brouard (2015)}

almost exclusively the organizational forms that social enterprises take in the Canadian context. We will discuss each in turn.

The cooperative movement in Canada touches almost every economic sector (with the manufacturing sector being the major exception) and has developed six distinct forms to address the different needs of these economic activities. Crucial to the cooperative form are the values of member ownership and control through democratic processes and the economic betterment of members through product quality, price and/or dividend. First, and most common, are consumer cooperatives (including housing, and goods and services cooperatives), which are focused on the delivery of specific consumer goods to members at affordable prices-the key examples being in natural and organic food, outdoor equipment, cooperative advocacy groups, and full-service supermarkets in rural and urban underprivileged areas (Neechi Foods in Winnipeg, Manitoba, is an excellent example of this type of social enterprise).

Secondly, there is the historically important form of producer cooperatives, which link up producers (usually agricultural producers, including fisheries) to marketing cooperatives to bring goods to market, thereby creating economies of scale for smaller producers as well as significant economic dividends for producers. In every region of Canada, producer cooperatives have emerged (historically in farm marketing), and continue to emerge, especially in niche and high-quality food sectors like organic food. They have also been particularly important to the development of the economies in each region and cultural group, and continue to be an important part of the identity of these regions.

Thirdly, worker cooperatives have emerged to provide the social good of work and economic security for their members. While there are historical worker cooperatives in resource extraction (in fishery or forestry for example) in many parts of Canada, the key areas of emergence in the last thirty years are in goods and services such as fair trade products (namely coffee, tea, chocolate, and sugar) and retail, construction, and a variety of specialty services and goods.

Fourthly, financial (credit unions) and insurance cooperatives are technically a type of consumer cooperative, but have developed into their own unique type of cooperative, with specific legislation and economic clout beyond any other cooperative sector. While these cooperatives have been experiencing increasing mergers and acquisitions over the past decade, with very few new financial cooperatives emerging, they are important players as financers and facilitators of other forms of cooperatives and, potentially, social enterprise. For example, Vancity Credit Union and other British Columbia-based finance co-operatives have underwritten much of the social enterprise sector development in the province.

Fifthly, cooperatives have also innovated over their long history in their governance structures, creating new forms of cooperative, specifically federations and other amalgamated organizations, which have become facilitators of cooperative social enterprises. Perhaps the most famous international organization of this type is Mondragon in the Basque region of Spain. In Canada, the most famous forms of federated cooperatives are the Co-operators Insurance Co-operative and Desjardins Credit Union. There are also new forms of cooperatives emerging in both the service (for example the provincial and national cooperative organizations) and product sectors (federations of cooperative food-buying clubs for example), as well as cooperatives that have their own specific legislative frameworks (such as renewable energy cooperatives in Ontario), which focus on achieving new and emerging social goals, member economic benefit, and regional economic development. 


\section{McMurtry \& Brouard (2015)}

The sixth and final form of cooperative enterprise in Canada are the multi-stakeholder or, in Québec, solidarity co-operatives, which combine different member groups (for example consumers and workers) in one cooperative to achieve the broad social goals articulated by those member groups within a single economic organization. So far, these have been very hard to develop but could become increasingly popular.

The co-operative "set" of social enterprises (including the nonprofit cooperatives-although inclusion of them under the umbrella of social enterprise is contested) in Canada can be therefore seen to be active in a variety of fields of economic activity, to serve a broad and diverse series of social goals, and to employ a range of governance structures, depending on the membership and stakeholders with which the co-operative is concerned. It would not be an overstatement to claim that co-operatives have the most developed legislative frameworks and practical experience of all social enterprises in Canada, even if they are often not considered by policy makers, or the public at large, as the most interesting form of social enterprise.

Non-profit organizations in Canada are also active in every region of Canada and have a long and varied history in the social enterprise realm. Despite provincial regulation of incorporation (e.g., via various provincial "society acts"), the fact that the federal government can award them charitable status (which comprise about half of registered nonprofits in Canada) means that they are much more closely connected to the federal government, as opposed to provincial or municipal entities, and therefore their organizational form is far less variant. This is not to say that the range of activities with which non-profits are involved is in any way singular. In fact, they are remarkably diverse in activity, even if their governance structures tend to be similar, with an independent management team and a volunteer board responsible for strategic decisions. This diversity is expanding with the recent tendency for non-profits to be engaged not just in service delivery, which would not, under most definitions, be considered social enterprise proper, but also in incubating and becoming reliant upon incomegenerating enterprises, either as part of the core activities of the nonprofit or as wholly-owned subsidiaries of these entities.

Community development/interest $(\mathrm{CD} / \mathrm{Cl})$ organizations in Canada form an emergent (although they began to emerge in the 1960s) set of social enterprises that are often on the cutting edge of policy and practice in Canada. Again, like co-operatives and non-profit organizations, $\mathrm{CD} / \mathrm{Cl}$ enterprises have a variety of fields of activities, social missions and target groups. However, unlike the previous two types of social enterprise, they are not as well articulated in policy, legislation, or governance at the national level as $C D / C l$ organization (although many are incorporated as non-profits or co-operatives). Indeed, outside of Quebec and the Atlantic region, these organizations are largely self-regulating as $\mathrm{CD} / \mathrm{Cl}$ entities and entrepreneurial in their social goals and organizational structure. These are essentially organizations born of social movements or social movement actors. A good exemplar of these types of organization across Canada is the unregulated "fairly traded" or "level trading" organizations (as opposed to the certified "fair trade" and largely co-operative businesses). These businesses undoubtedly have a social mission; however, the regulation of their mission by the state, or an independent NGO-regulating body, is entirely absent. They therefore rely on trust and the belief of their clientele in their authenticity, and the quality of their boards or staff, which raises questions about the guarantee of their social mission and their status as social enterprises. This type of unregulated and unauthenticated social enterprise loosely associated with a social mission or social movement is becoming more and more prevalent in an increasingly crowded "social business" marketplace and raises the question of the role of the state and NGOs in ensuring verifiable social content. 


\section{McMurtry \& Brouard (2015)}

Indigenous business forms the fourth set of social enterprises in the Canadian context. Again these social enterprises have a broad field of activity, including work integration, tourism, basic good provision, culturally specific goods and services, resource extraction and trade in commercial goods. However, what distinguishes this form of social enterprise from other social enterprise forms, such as co-operatives, non-profits, and community development/interest corporations, is their specific focus on Indigenous community well-being as their primary social goal. In some cases (Membertou First Nation in Cape Breton being one), the economic activities that the First Nation is involved in are almost indistinguishable from capitalist businesses (such as brand name hotels, restaurants, and gas stations), except for the fact that they are incorporated and owned by Indigenous communities, usually through their band councils, who use the profits to develop community resources such as schools and infrastructure. In the context of ongoing economic colonialization, these social enterprises are distinct and challenge dominant understandings of social enterprises. For example, many Indigenous economic entities are, both in law and practice, collectively owned if they are located on band land or use band resources. Many of the sources of capital and resources that facilitate individual businesses are also directly connected to Indigenous government or treaty rights. For example, the tax exemptions, as a result of treaty rights, can facilitate Indigenous businesses (often in "sin" businesses such as casinos, gas stations, and cigarette and alcohol retailers) that can use the profits from these activities to fund social projects for the good of the community. As the youngest and fastest growing demographic group in Canada, Indigenous people have enormous potential as sites of social entrepreneurship and social enterprise activity.

Finally, businesses with a social mission form a distinct type of social enterprise, mainly in the central and western provinces of Canada, although the inclusion of these entities within the social enterprise family is contested. These are often, but not exclusively, traditional sole-proprietorship or even publically traded corporations that articulate a strong social mission in one area of their businesses. They can also be part of, or strongly associated with, foundations or other granting agencies. Again, the types of activity that these organizations can be involved in are widely variable, because inclusion requires simply some kind of publically recognized social mission. What distinguishes them from the first three forms is that they are traditional for-profit businesses first. The fact that they are incorporated to achieve, or focus on, or are "retrofitted" to target an identifiable social mission is what their proponents argue makes them social enterprises. It is likely that, if the definition of social enterprise remains an open category in the public's minds and in policy circles, this type of social enterprise will become increasingly popular as businesses try to "social-wash" their activities.

Table A summarizes the five social enterprise models in Canada along the legal structure and ownership dimensions and provides a few examples of social enterprises for each model. 
McMurtry \& Brouard (2015)

Table A: Summary of Canadian social enterprise models

\begin{tabular}{|c|c|c|c|c|c|}
\hline Models & Cooperative & $\begin{array}{l}\text { Non-profit } \\
\text { organization }\end{array}$ & $\begin{array}{l}\text { Community } \\
\text { development /interest } \\
\text { organization }\end{array}$ & $\begin{array}{l}\text { First Nation } \\
\text { businesses }\end{array}$ & $\begin{array}{l}\text { Business with a } \\
\text { social mission }\end{array}$ \\
\hline $\begin{array}{l}\text { Legal } \\
\text { structure }\end{array}$ & Cooperative & $\begin{array}{l}\text { Non-profit corporation; } \\
\text { Charities (charitable } \\
\text { organization, } \\
\text { foundation (private, } \\
\text { public) } \\
\text { Association; } \\
\text { Informal Group }\end{array}$ & $\begin{array}{l}\text { Community enterprise; } \\
\text { Community-owned } \\
\text { organizations; } \\
\text { Associations }\end{array}$ & $\begin{array}{l}\text { Non-profit } \\
\text { corporation; For- } \\
\text { profit } \\
\text { corporation; } \\
\text { Partnership; } \\
\text { Unicorporated } \\
\text { business }\end{array}$ & $\begin{array}{l}\text { For-profit } \\
\text { corporation; } \\
\text { Partnership; } \\
\text { Unincorporated } \\
\text { business; } \\
\text { Community } \\
\text { Interest Company } \\
\text { (CIC); } \\
\text { Community } \\
\text { Contribution } \\
\text { Company (CCC) }\end{array}$ \\
\hline Ownership & Individuals & Members & $\begin{array}{l}\text { Community } \\
\text { Government (local, } \\
\text { provincial, federal) }\end{array}$ & First Nation & $\begin{array}{l}\text { Public } \\
\text { Individuals }\end{array}$ \\
\hline Examples & $\begin{array}{l}\text { MEC; Agropur, Co- } \\
\text { op Atlantic, } \\
\text { Desjardins, Alterna, } \\
\text { Sumac Worker } \\
\text { cooperative, Neechi } \\
\text { Foods }\end{array}$ & FoodShare, SABRI & $\begin{array}{l}\text { Carrefour Jeunesse } \\
\text { Emploi, ZEC }\end{array}$ & $\begin{array}{l}\text { KUTERRA } \\
\text { Membertou }\end{array}$ & $\begin{array}{l}\text { Groupe Convex, } \\
\text { Communauto }\end{array}$ \\
\hline
\end{tabular}

\section{CONCLUSION}

It is important to remind the reader that while these models of social enterprise have emerged across the country, they are substantially nested within the cultural contexts discussed above. For example, within Québec, at least the first three of these five sets of social enterprises are nested within a strong policy and social movement context that is understood as the social economy. In fact, these models of social enterprise are often massaged to purpose by a myriad of organizations to advance their missions and goals-for example private foundations, public foundations, NGOs, etc. all develop and use these forms to articulate part of their social missions. Even when the model of social enterprise is in an emergent or minority position in a cultural context (business with a social mission in Québec, for example), it still tends to reflect a cultural context (the minority Anglophone communities in Montreal, for example, as advocates for business with a social mission in Québec). In other words, the climates that encourage social enterprises vary widely and are dependent on the history and context that have given rise to them. Further the fact that social enterprise models are chosen by a variety of social actors is a fact that cannot be ignored when discussing typologies and definitions. Social enterprises can be developed sui generis by communities, or individual entrepreneurs, or like-minded groups, based on a wide variety of social missions and goals, just as they can be "encouraged" by state policy at the national, provincial, or municipal level or imposed "top-down" by businesses, non-profit organizations, or foundations.

With the overarching framing outlined in this introduction in mind, we encourage the reader to explore the papers in this special edition, and to see social enterprises as they emerge in Canada as an exciting, diverse, and rich new component of the Canadian economy. 


\section{McMurtry \& Brouard (2015)}

\section{REFERENCES}

Bouchard, M.J., Cruz Filho, P., Zerdani, T., Claude, M. (2013). Report on social enterprises in Quebec. (Report on ICSEM project, December). Canada: ICSEM Canada Research Group.

Bouchard, M., Cruz Filho, P., \& Zerdani, T. (2015). Social enterprise concept and models in Québec. ANSERJ: Canadian Journal of Nonprofit and Social Economy Research / Revue canadienne de recherche sur les OSBL et l'économie sociale, 6(1), 42-62.

Brouard, F, McMurtry, J., \& Vieta, M. (2015). Social Enterprise Models in Canada - Ontario. ANSERJ: Canadian Journal of Nonprofit and Social Economy Research / Revue canadienne de recherche sur les OSBL et l'économie sociale, 6(1), 63-82.

Elson, P., \& Hall, P. (2012). Canadian Social Enterprises: Taking Stock. Social Enterprise Journal, 8(3), 216-236.

Elson, P.R., Hall, P., Leeson-Klym, S., Penner, D., \& Andres, J (2015). ICSEM - Social Enterprise in the Canadian Wes. ANSERJ: Canadian Journal of Nonprofit and Social Economy Research / Revue canadienne de recherche sur les OSBL et l'économie sociale, 6(1), 83-102.

Lionais, D. (2015). Social Enterprise in Atlantic Canada. ANSERJ: Canadian Journal of Nonprofit and Social Economy Research / Revue canadienne de recherche sur les OSBL et l'économie sociale, 6(1), 25-41.

Madill, J., Brouard, F., \& Hebb, T. (2010). Canadian social enterprises: An empirical exploration of social transformation, financial self-efficiency, and innovation. Journal of Nonprofit and Public Sector Marketing, 22(2), $135-151$.

McMurtry, JJ. (Ed.). (2010). Living Economics: Canadian Perspectives on the Social Economy, Co-operatives, and Community Economic Development. Toronto: Emond Montgomery Press.

Sangupta, U., Vieta, M., \& McMurtry, J.J. (2015). Indigenous Communities and Social Enterprises in Canada, ANSERJ: Canadian Journal of Nonprofit and Social Economy Research / Revue canadienne de recherche sur les OSBL et l'économie sociale, 6(1), 103-123.

Wuttunee, W. (2010). Aboriginal persectives on the social economy, co-operatives, and community economic development. Toronto, ON: Emond Montgomery Press.

\section{ABOUT THE AUTHORS / LES AUTEURS}

J.J. MCMURTRY, PhD, is Chair of Social Science, Graduate Program Director of the Social and Political Thought Program, and Associate Professor of Business and Society Program, York University, Toronto, Ontario. Email: jmcmurtr@yorku.ca .

François BROUARD, DBA, FCPA, FCA is Associate Professor at the Sprott School of Business, Carleton University and Director of the Sprott Centre for Social Enterprises (SCSE) / Centre Sprott pour les entreprises sociales (CSES), Ottawa, Ontario. Email: francois.brouard@carleton . 